\title{
Author Correction: North Atlantic variability and its links to European climate over the last 3000 years
}

\author{
Paola Moffa-Sánchez ${ }^{1} \&$ lan R. Hall ${ }^{1}$
}

Correction to: Nature Communications https://doi.org/10.1038/s41467-017-01884-8, published online 23 November 2017

In the original version of this Article, the third sentence of the first paragraph of the "Changes in the input of polar waters into the Labrador Sea" section of the Results originally incorrectly read "During the spring-summer months, after the winter convection has ceased in the Labrador Sea, its northwest boundary currents (the EGC and IC) support restratification of the surface ocean through lateral transport." The correct version states "northeast" instead of "northwest".

The fifth sentence of the second paragraph of the same section originally incorrectly read "In contrast, in the western section of the Nordic Seas, under the presence of warm Atlantic waters of the Norwegian Current, Nps was found to calcify deeper in the water column (100-200 m), whereas in the east under the influence of the EGC polar waters it calcified closer to the surface at a similar depth as $\mathrm{Tq}^{23}$." The correct version states "eastern" instead of "western" and "west" instead of "east".

The seventh sentence of the same paragraph originally incorrectly read "Small/large differences in $\Delta \delta^{18} \mathrm{O}_{\mathrm{Nps}-\mathrm{Tq}}$ indicating increased/ decreased presence of warm and salty Atlantic IC waters vs. polar EGC waters in the upper water column, respectively." The correct version starts 'Large/small' rather than "Small/large".

These errors have been corrected in both the PDF and the HTML versions of the Article.

Published online: 15 February 2018

\footnotetext{
(c) Open Access This article is licensed under a Creative Commons Attribution 4.0 International License, which permits use, sharing, adaptation, distribution and reproduction in any medium or format, as long as you give appropriate credit to the original author(s) and the source, provide a link to the Creative Commons license, and indicate if changes were made. The images or other third party material in this article are included in the article's Creative Commons license, unless indicated otherwise in a credit line to the material. If material is not included in the article's Creative Commons license and your intended use is not permitted by statutory regulation or exceeds the permitted use, you will need to obtain permission directly from the copyright holder. To view a copy of this license, visit http://creativecommons.org/licenses/by/4.0/.
}

(c) The Author(s) 2018

\footnotetext{
${ }^{1}$ School of Earth and Ocean Sciences, Cardiff University, CF10 3YE Cardiff, UK. Correspondence and requests for materials should be addressed to P.M-Sán. (email: moffasanchezp1@cardiff.ac.uk)
} 